\title{
Biocatalysis and Biotransformations
}

\author{
Manuel Ferrer (i) \\ Institute of Catalysis, Consejo Superior de Investigaciones Científicas, 28049 Madrid, Spain; mferrer@icp.csic.es; \\ Tel.: +34-91-5854872 \\ Received: 14 May 2018; Accepted: 17 May 2018; Published: 17 May 2018

\section{Background}

The complexity and chemical diversity of industrial substrates make their transformation challenging [1]. Chemists mostly use pure solvents for chemical conversions, and they cannot imagine water as the best solvent. We cannot expect that an enzyme exists that can work in pure solvents and that a natural limit will exist. For this reason, chemists mostly use inorganic catalysts for chemical conversions, and they commonly cannot imagine using enzymes as a first choice, if it was not because, sometimes, chemistry does not find a solution or because there is an environmental concern around the chemical process [2]. Only in those cases are enzymatic conversions considered. Life sciences and biotechnology are, thus, promising frontiers for industrial biotransformations. The vast breadth of biotechnology used in modern economies opens new routes to sustainable developments. Enzymes generate approximately $\$ 5$ billion/year with $\$ 7$ billion/year forecasted for the end of 2018 (www.luxresearchinc.com). Each industrial process is different and the correct enzyme needs to be identified and/or optimized for the industrial application. Over 500 industrial products are being made using enzymes and about 150 industrial processes use enzymes or whole microbial cell catalysts [3,4]. The constant search for new enzymatic catalysts comes from the demand of constantly evolving industrial processes and the bio-economy, in which enzyme properties are appreciated. Indeed, enzymes fold into exquisite three-dimensional structures which catalyze kinetically challenging reactions, achieving high rate enhancements with excellent control over the mechanism, chemochemistry, regiochemistry, and stereochemistry of their substrates $[5,6]$.

Most industrially relevant enzymes are of microbial origin and their discovery, purification, and manufacture are key steps in industrial bioprocesses. Nature and modern microbiology permits unprecedented accessibility to highly diverse enzymes. However, we can only cultivate $<1 \%$ of environmental bacteria [7], and this number significantly drops when considering strains requiring extreme conditions for cultivation. Metagenomics overcomes this limitation by isolating microbial community genomic DNA. Metagenomics gave us access to the vast natural enzyme variation [8]. These enzymes, which may have been adapted to so-called "standard" conditions for growth (room temperature, neutral $\mathrm{pH}$, and no pressure) as well as to extreme environments, may haveacquired biochemical characteristics that can benefit biotechnological, industrial, and environmental processes in many cases. It has become increasingly clear that a significant stumbling block to novel enzyme discovery in current genomics and metagenomics may come not only from sample richness, which can be solved by sampling thousands of sites across the planet including extreme niches, but also from our ability to deeply mine environmental genomes and metagenomes in a time-efficient manner in connection to industrial needs [6]. Researchers have partially solved these shortcomings by technical innovations, which include screening a large number of genomes and metagenomes to increase the success rate, designing new screening methods including microfluidics, using multiple tandem vector and host systems for screening and expression, designing advanced bioinformatics applied to enzyme discovery for sequence information, and etc. 
With the discovery of the mechanisms by which proteins fold and the development of protein engineering and computational tools, the engineering and re-design of natural enzymes or even the design of enzymes from scratch became possible [9-11]. Whatever the capacity to identify or engineer new and better performing enzymes, it is increasingly recognized that biocatalysts are delicate materials that need to be stabilized to survive a range of challenging conditions typically used in industrial processes and any conversion in general. Thus, in order to construct efficient enzymes, they need to be stabilized. Distinct combinatorial and rational methods to generate such stabilized biocatalysts are required, regardless of the apparent relative improvements at the end of the process [12].

Whatever the utilization of free or immobilized enzymes (in the form of native or engineered proteins or whole cells), the production of chemicals by enzyme catalysts offers a promising opportunity to improve overall economics and sustainability. Indeed, the overall bio-based products currently displace about 300 million gallons of petroleum per year, which is equivalent to taking 200,000 cars off the road [1]. Also, a reduction in greenhouse gas emissions for bio-derived products relative to their petroleum counterparts was demonstrated [1]. The market for bio-based chemicals reached more than $\$ 20$ billion in 2018 and is expected to continue growing. Identifying enzymatic catalysts capable of transforming an ample set of chemicals, including those present in different feed-stocks, may be of interest to broaden enzyme applicability and process developments. This will contribute to reach the ambitious objectives of biotechnology programs such as the Bio-based Industry (BBI) program (http:/ / biconsortium.eu), whose objective is to promote the production of new bio-based products.

\section{The Present Issue}

I am honored to be the Guest Editor of a thematic issue published in the Catalysts journal for the first time. I would especially like to thank Jiuyu Guo, Senior Assistant Editor, and the entire staff of the Catalysts Editorial Office, who productively collaborated with me. Furthermore, I would like to thank all of the authors contributing their papers to this issue for their excellent work. It is comprised of twenty-five research articles. As pointed out in the background, the meaning of this issue is to underline new trends in Biocatalysis and Biotransformations. With this aim, special attention has been paid to identifying, engineering, and immobilizing known or new enzymes so as to increase the progress and diversity of enzyme conversions, as well as describing recent advances in the applications of enzymes (free or immobilized) and whole cell transformations for the synthesis of valuable chemicals.

Among the research articles presented in this issue, an ample set of enzymes have been investigated for biocatalytic processes. They include hydrolases (esterases, lipases, hydantoinase, and beta-galactosidases), transferases (2'-deoxyribosyltransferases, hypoxanthine-guanine-xanthine phosphoribosyltransferases, and methionine adenosyltransferases), and oxidoreductases (CYP153A monooxygenase, carboxylic acid reductase, aldehyde reductases, $3 \beta$-hydroxysteroid dehydrogenases, Baeyer-Villiger monooxygenases, polycyclic ketone monooxygenases, nicotine hydroxylase, pyrroloquinoline quinone-dependent alcohol dehydrogenase, glutathione peroxidase, laccase, amine dehydrogenases, and NADH oxidases), as well as racemases and $3 \beta$-hydroxysteroid isomerases. Most studies reported the use of free or immobilized enzyme preparations, but whole cells transformations using cells expressing desired enzymes or new strains containing enzyme activities of interest have been also presented. Note that oxidoreductases, transferases, and hydrolases are among the three types of enzymes most used at an industrial level [1,4].

The biotransformations covered in this issue include those involved in the synthesis of many value-added chemicals, such as nucleoside, purine, pyridine, steroid, $\alpha$, $w$-diols $\left(C_{8}-C_{16}\right)$ and furan derivatives, 2-ethylhexyl salicylate (which is an organic compound used as an ingredient in sunscreens and cosmetics to absorb UVB (ultraviolet) rays from the sun), optically active sulfoxides and amines, L-amino acids, molecules with probiotic properties (such as lactulose esters and oligosaccharides), and other molecules with a wide application in the field of medicine (such as S-adenosylmethionine). In all cases, the enzymatic syntheses were shown to represent an attractive alternative to chemical synthesis because of their high specificity, high efficiency, and low production of pollutants. 
In more detail, Fresco-Taboada and coworkers investigated the synthesis of modified nucleosides by using novel 2'-deoxyribosyltransferases [13]. Acosta and coworkers reported the synthesis of purine derivatives by the sequential action of 2 '-deoxyribosyltransferases and hypoxanthine-guanine-xanthine phosphoribosyltransferases [14]. The utilization of renewable free fatty acids as a source of $\alpha, \omega$-diols $\left(\mathrm{C}_{8}-\mathrm{C}_{16}\right)$ by the action of CYP153A monooxygenase, carboxylic acid reductase, and aldehyde reductases was demonstrated by Ahsan and coworkers [15]. Huang and coworkers investigated the synthesis of 2-ethylhexyl salicylate using lipases [16]. García-Fernández and coworkers investigated the synthesis of 4-ene-3-ketosteroids by using $3 \beta$-hydroxysteroid dehydrogenases/isomerases [17]. De Gonzalo and coworkers successfully reported the synthesis of optically active sulfoxides using Baeyer-Villiger monooxygenases and polycyclic ketone monooxygenases [18]. The conversion of 6-hydroxy-3-succinoylpyridine into 2,5-dihydroxypyridine by nicotine hydroxylases was investigated by Wei and coworkers [19]. The synthesis of S-adenosylmethionine was investigated by Niu and coworkers using methionine adenosyltransferases [20]. L-amino acid production was investigated by Rodríguez-Alonso and coworkers who used double enzymatic systems based on the application of racemases and hydantoinases to produce norvaline, norleucine, and homophenylalanine [21]. The conversion of furans, including 5-(hydroxymethyl) furfural (HMF) and furfural, by Bayer-Villiger monooxygenases was investigated by Kumar and Fraaije [22]. Chávez-Flores investigated the application of lipases for the synthesis of lactulose esters [23]. Whole cells biocatalysts containing amine dehydrogenases and NADH oxidases were also employed for kinetic resolutions of racemic amines by Jeon and coworkers [24]. Whole cells of new isolates were also employed by Yañez-Ñeco and coworkers, and they reported the production of galactooligosaccharides [25].

Besides the above conversions, those of complex molecules such as sugar maple bark, cellulose-based materials, and wastewater were also covered in this issue, as well as the decolorization of dyes and energy generation. In particular, the conversion of complex molecules such as sugar maple bark and cellulose-based materials into several chemical backbones was investigated by Koumba-Yoya and coworkers [26] and Haske-Cornelius and coworkers [27], exemplifying the capacity of bioocatalysis as source of chemicals from complex biomasses and feedstocks. Conversion of other complex molecule-containing systems, such as wastewater, was investigated by $\mathrm{Li}$ and coworkers using new Mn-containing catalases [28]. Site-directed mutagenesis as a tool to improve catalytic performance was investigated by Wang and coworkers; authors introduced mutations into a bacterial laccase to improve indigo decolorization [29].

Several investigations in this issue focused on investigating the effect of different immobilization methods on biocatalyst performance. Thus, Tu and coworkers focused on improving the catalytic performance of immobilized lipase on clay/chitosan composites [30]. Sakurada and coworkers increased the long-term stability and catalytic current density of pyrroloquinoline quinone-dependent alcohol dehydrogenase when immobilized on a redox polymer, aminoferrocene, which was attached on an electrode [31]. Finally, several aminated-agarose beads were employed to increase the catalytic efficiency of beta-galactosidases via glutaraldehyde chemistry using different strategies by Zaak and coworkers [32].

Another important aspect which, in my opinion, additionally deserved research, concerns the application of methods other than protein engineering and immobilization, which could lead to more efficient biocatalysis. Two important examples are herein reported by Wang and coworkers, who designed and synthesized cyclodextrin derivatives which could serve as stable glutathione peroxidase mimics for the removal of $\mathrm{H}_{2} \mathrm{O}_{2}$ and other hydroperoxides [33]. Similarly, Huang and coworkers design selenium-containing trypsin mimics that increase the substrate binding capacity and stability of glutathione peroxidases [34]. Maslova and coworkers investigated how lactonase activity of organophosphorus hydrolases can be increased by producing enzyme-polyelectrolyte complexes with poly-L-glutamic acid or poly-L-aspartic acid and adding small concentrations of antibiotics [35].

Finally, in the present issue, Coscolín and coworkers [36] and Nguyen and coworkers [37] investigated the properties and catalytic performance of biocatalysts newly isolated from genomes 
and metagenomes. In particular, Coscolín and coworkers investigated an ample set of metagenomicsderived esterases and lipases to reveal the extent by which promiscuity and selectivity co-exist in these catalytically-important biocatalysts, so as to identify chiral selective and promiscuous esterases and lipases. Nguyen and coworkers presented the complete genome sequence of Methylomonas sp. DH-1 to investigate the application of this strain for the production of succinate from methane. This is because of the presence in its genome of a set of required enzymes.

In conclusion, the present issue, "Biocatalysis and Biotransformations", is of great interest and relevance as it covers all aspects, from enzyme and microbe discovery and the investigation of their enzymatic properties, to enzyme immobilization and engineering, and to applications of important chemical scaffolds and applications related to health and energy.

Acknowledgments: This editorial work was possible because the funding received from the European Union's Horizon 2020 research and innovation program (Blue Growth: Unlocking the potential of Seas and Oceans) through the Project 'INMARE' under grant agreement No. 634486, the grants PCIN-2014-107 (within ERA NET IB2 grant nr. ERA-IB-14-030-MetaCat), PCIN-2017-078 (within the ERA-MarineBiotech grant ProBone), BIO2014-54494-R and BIO2017-85522-R from the Spanish Ministry of Economy and Competitiveness, and the European Regional Development Fund (ERDF).

Conflicts of Interest: The author declares no conflicts of interest.

\section{References}

1. Martínez-Martínez, M.; Bargiela, R.; Ferrer, M. Metagenomics and the search for industrial enzymes. In Biotechnology of Microbial Enzymes, 1st ed.; Brahmachari, G., Demain, A.L., Adrio, J.L., Eds.; Academic Press: Chennai, India, 2015; pp. 167-184.

2. Alcalde, M.; Ferrer, M.; Plou, F.J.; Ballesteros, A. Environmental biocatalysis: From remediation with enzymes to novel green processes. Trends Biotechnol. 2006, 24, 281-287. [CrossRef] [PubMed]

3. Adrio, J.L.; Demain, A.L. Microbial enzymes: Tools for biotechnological processes. Biomolecules 2014, 4, 117-139. [CrossRef] [PubMed]

4. Martínez-Martínez, M.; Bargiela, R.; Coscolín, C.; Navarro-Fernández, J.; Golyshin, P.N.; Ferrer, M. Functionalization and modification of hydrocarbon-like molecules guided by metagenomics: Enzymes most requested at the industrial scale for chemical synthesis as study cases. In Consequences of Microbial Interactions with Hydrocarbons, Oils, and Lipids: Production of Fuels and Chemicals; Lee, S.Y., Ed.; Springer International Publishing AG: Cham, Switzerland, 2016; pp. 1-26.

5. Schmid, A.; Dordick, J.S.; Hauer, B.; Kiener, A.; Wubbolts, M.; Witholt, B. Industrial biocatalysis today and tomorrow. Nature 2001, 409, 258-268. [CrossRef] [PubMed]

6. Martínez-Martínez, M.; Coscolín, C.; Santiago, G.; Chow, J.; Stogios, P.; Bargiela, R.; Gertler, C.; Navarro-Fernández, J.; Bollinger, A.; Thies, S.; et al. Determinants and prediction of esterase substrate promiscuity patterns. ACS Chem. Biol. 2018, 13, 225-234. [CrossRef] [PubMed]

7. Yarza, P.; Yilmaz, P.; Pruesse, E.; Glöckner, F.O.; Ludwig, W.; Schleifer, K.H.; Whitman, W.B.; Euzéby, J.; Amann, R.; Rosselló-Móra, R. Uniting the classification of cultured and uncultured bacteria and archaea using 16S rRNA gene sequences. Nat. Rev. Microbiol. 2014, 12, 635-645. [CrossRef] [PubMed]

8. Ferrer, M.; Martínez-Martínez, M.; Bargiela, R.; Streit, W.R.; Golyshina, O.V.; Golyshin, P.N. Estimating the success of enzyme bioprospecting through metagenomics: Current status and future trends. Microb. Biotechnol. 2016, 9, 22-34. [CrossRef] [PubMed]

9. Korendovych, I.V.; DeGrado, W.F. Catalytic efficiency of designed catalytic proteins. Curr. Opin. Struct. Biol. 2014, 27, 113-121. [CrossRef] [PubMed]

10. Molina-Espeja, P.; Viña-Gonzalez, J.; Gomez-Fernandez, B.J.; Martin-Diaz, J.; Garcia-Ruiz, E.; Alcalde, M. Beyond the outer limits of nature by directed evolution. Biotechnol. Adv. 2016, 34, 754-767. [CrossRef] [PubMed]

11. Santiago, G.; Martínez-Martínez, M.; Alonso, S.; Bargiela, R.; Coscolín, C.; Golyshin, P.N.; Guallar, V.; Ferrer, M. Rational engineering of multiple active sites in an ester hydrolase. Biochemistry 2018, 57, 2245-2255. [CrossRef] [PubMed]

12. Bommarius, A.S.; Paye, M.F. Stabilizing biocatalysts. Chem. Soc. Rev. 2013, 42, 6534-6565. [CrossRef] [PubMed] 
13. Fresco-Taboada, A.; Fernández-Lucas, J.; Acebal, C.; Arroyo, M.; Ramón, F.; de la Mata, I.; Mancheño, J. 2'-Deoxyribosyltransferase from Bacillus psychrosaccharolyticus: A mesophilic-like biocatalyst for the synthesis of modified nucleosides from a psychrotolerant bacterium. Catalysts 2018, 8, 8. [CrossRef]

14. Acosta, J.; del Arco, J.; Martinez-Pascual, S.; Clemente-Suárez, V.; Fernández-Lucas, J. One-pot multienzymatic production of purine derivatives with application in pharmaceutical and food industry. Catalysts 2018, 8, 9. [CrossRef]

15. Ahsan, M.; Sung, S.; Jeon, H.; Patil, M.; Chung, T.; Yun, H. Biosynthesis of medium- to long-chain $\alpha, \omega$-diols from free fatty acids using CYP153A monooxygenase, carboxylic acid reductase, and $E$. coli endogenous aldehyde reductases. Catalysts 2018, 8, 4. [CrossRef]

16. Huang, S.; Hung, T.; Liu, Y.; Kuo, C.; Shieh, C. Green synthesis of ultraviolet absorber 2-ethylhexyl salicylate: Experimental design and artificial neural network modeling. Catalysts 2017, 7, 342. [CrossRef]

17. García-Fernández, J.; Galán, B.; Felpeto-Santero, C.; Barredo, J.; García, J. Production of 4-ene-3-ketosteroids in Corynebacterium glutamicum. Catalysts 2017, 7, 316. [CrossRef]

18. De Gonzalo, G.; Fürst, M.; Fraaije, M. Polycyclic ketone monooxygenase (PockeMO): A robust biocatalyst for the synthesis of optically active sulfoxides. Catalysts 2017, 7, 288. [CrossRef]

19. Wei, T.; Zang, J.; Zheng, Y.; Tang, H.; Huang, S.; Mao, D. Characterization of a novel nicotine hydroxylase from Pseudomonas sp. ZZ-5 that catalyzes the conversion of 6-hydroxy-3-succinoylpyridine into 2,5-dihydroxypyridine. Catalysts 2017, 7, 257. [CrossRef]

20. Niu, W.; Cao, S.; Yang, M.; Xu, L. Enzymatic synthesis of S-adenosylmethionine using immobilized methionine adenosyltransferase variants on the 50-mm scale. Catalysts 2017, 7, 238.

21. Rodríguez-Alonso, M.; Rodríguez-Vico, F.; Las Heras-Vázquez, F.; Clemente-Jiménez, J. L-Amino acid production by a immobilized double-racemase hydantoinase process: Improvement and comparison with a free protein system. Catalysts 2017, 7, 192. [CrossRef]

22. Kumar, H.; Fraaije, M. Conversion of furans by Baeyer-Villiger monooxygenases. Catalysts 2017, 7, 179. [CrossRef]

23. Chávez-Flores, L.; Beltran, H.; Arrieta-Baez, D.; Reyes-Duarte, D. Regioselective synthesis of lactulose esters by Candida antarctica and Thermomyces lanuginosus lipases. Catalysts 2017, 7, 263. [CrossRef]

24. Jeon, H.; Yoon, S.; Ahsan, M.; Sung, S.; Kim, G.; Sundaramoorthy, U.; Rhee, S.; Yun, H. The Kinetic resolution of racemic amines using a whole-cell biocatalyst co-expressing amine dehydrogenase and NADH oxidase. Catalysts 2017, 7, 251. [CrossRef]

25. Yañez-Ñeco, C.; Rodriguez-Colinas, B.; Amaya-Delgado, L.; Ballesteros, A.; Gschaedler, A.; Plou, F.; Arrizon, J. Galactooligosaccharide production from Pantoea anthophila strains isolated from "Tejuino", a Mexican traditional fermented beverage. Catalysts 2017, 7, 242. [CrossRef]

26. Koumba-Yoya, G.; Stevanovic, T. Transformation of sugar maple bark through catalytic organosolv pulping. Catalysts 2017, 7, 294. [CrossRef]

27. Haske-Cornelius, O.; Pellis, A.; Tegl, G.; Wurz, S.; Saake, B.; Ludwig, R.; Sebastian, A.; Nyanhongo, G.; Guebitz, G. Enzymatic Systems for Cellulose Acetate Degradation. Catalysts 2017, 7, 287. [CrossRef]

28. Li, H.; Yu, Q.; Wang, H.; Cao, X.; Ma, L.; Li, Z. A new homo-hexamer Mn-containing catalase from Geobacillus sp. WCH70. Catalysts 2017, 7, 277. [CrossRef]

29. Wang, J.; Lu, L.; Feng, F. Improving the indigo carmine decolorization ability of a bacillus amyloliquefaciens laccase by site-directed mutagenesis. Catalysts 2017, 7, 275. [CrossRef]

30. Tu, N.; Shou, J.; Dong, H.; Huang, J.; Li, Y. Improved catalytic performance of lipase supported on clay/chitosan composite beads. Catalysts 2017, 7, 302. [CrossRef]

31. Sakurada, Y.; Takeda, K.; Ohno, H.; Nakamura, N. Immobilization of pyrroloquinoline quinone-dependent alcohol dehydrogenase with a polyion complex and redox polymer for a bioanode. Catalysts 2017, 7, 296. [CrossRef]

32. Zaak, H.; Peirce, S.; de Albuquerque, T.; Sassi, M.; Fernandez-Lafuente, R. Exploiting the versatility of aminated supports activated with glutaraldehyde to immobilize $\beta$-galactosidase from Aspergillus oryzae. Catalysts 2017, 7, 250. [CrossRef]

33. Wang, L.; Qu, X.; Xie, Y.; Lv, S. Study of 8 types of glutathione peroxidase mimics based on $\beta$-cyclodextrin. Catalysts 2017, 7, 289. [CrossRef]

34. Huang, Y.; Ge, D.; Zong, H.; Yin, J.; Qu, X.; Lv, S. Active site mimicry of glutathione peroxidase by glutathione imprinted selenium-containing trypsin. Catalysts 2017, 7, 282. [CrossRef] 
35. Maslova, O.; Aslanli, A.; Stepanov, N.; Lyagin, I.; Efremenko, E. Catalytic characteristics of new antibacterials based on hexahistidine-containing organophosphorus hydrolase. Catalysts 2017, 7, 271. [CrossRef]

36. Coscolín, C.; Martínez-Martínez, M.; Chow, J.; Bargiela, R.; García-Moyano, A.; Bjerga, G.; Bollinger, A.; Stokke, R.; Steen, I.; Golyshina, O.; et al. Relationships between substrate promiscuity and chiral selectivity of esterases from phylogenetically and environmentally diverse microorganisms. Catalysts 2018, 8, 10. [CrossRef]

37. Nguyen, A.; Hwang, I.; Lee, O.; Hur, D.; Jeon, Y.; Hadiyati, S.; Kim, M.; Yoon, S.; Jeong, H.; Lee, E. Functional analysis of Methylomonas sp. DH-1 genome as a promising biocatalyst for bioconversion of methane to valuable chemicals. Catalysts 2018, 8, 117. [CrossRef]

2018 by the author. Licensee MDPI, Basel, Switzerland. This article is an open access article distributed under the terms and conditions of the Creative Commons Attribution (CC BY) license (http://creativecommons.org/licenses/by/4.0/). 